\title{
地表面アレー測定による常時微動の波群特性の抽出 CHARACTERISTICS OF WAVE GROUP OF MICROTREMORS OBTAINED BY ARRAY MEASUREMENT
}

\author{
田村 保*, 永井大海 ${ }^{* *}$, 小久保 裕***, 住田裕.志**** \\ Tamotsu TAMURA, Ohmi NAGAI, Hiroshi KOKUBO and Hiroshi SUMITA
}

\begin{abstract}
Microtremor measurement by ground surface array have been done at two reclaimed site located in Tokyo Bay area. Phase velocity and traveling direction of microtremors are determined from the frequency-wavenumber spectrum analysis. In the frequency range of surface ground natural period, existence of two wave group was found at both site. One wave group has the same dispersion characteristics of Love wave and the other is traveling with high phase velocity compared with the shear wave velocity of base layer. In the frequency-wavenumber spectrum, there is no evidence of existence of Rayleigh wave in this frequency range.
\end{abstract}

Keywords : short-period microtremors, Rayleigh wave, Love wave, frequency-wave number spectrum, natural site period, reclaimed land 短周期微動, レーリー波, ラブ波, 周波数-波数スペクトル, 地盤の固有周期, 埋立 地

\section{1. 序 論}

微動を利用して表層地盤の地盤特性を推定する試みは 金井ら”の研究を緒として，現在にいたるまで種々の新 しい試みが加えられながら発展してきた。初期において は, 周期 1 秒程度以下の短周期微動の利用に関して S 波 の重複反射が支配的であると考え, 微動のスペクトル解 析結果から求まる卓越周波数により地盤特性を推定する 方法が多用されてきた。，そのため, 微動の測定は表面波 を励起させるような䫓著な振動源の影響の少ない深夜に 実施することが多かった。しかし，短周期の微動の卓越 振動数は, このような測定の際の多大な努力にもかかわ らす，表層地盤の固有周期との対応は良くない場合も少 なくなく, 短周期微動の工学的有效性に関して疑問の声 も少なくなかった。一方，周期 1 秒以上のやや長周期の 微動に対しては, 地表面アレーによる上下方向の微動の 測定から波動の位相速度とその伝播方向を求める試 み ${ }^{21-5)}$ がなされており, 微動の位相速度の分散特性の逆 解析からやや深い地下構造を推定する手法として検討が 進められている。地表面アレーによる測定では, 常時微
動計を適切に配置することにより短周期の微動の周波数 一波数スペクトルも求めることができ, 短周期の上下方 向の微動と地下構造の関係を検討した事例 ${ }^{(6)}$-15) も近年多 く見られる。特に，短周期の微動の地表面アレー測定で は, 表面波としてレイリー波の位相速度の分散特性を推 定し表層地盤の速度構造と関係づけているために, 従来 のような深夜に微動の測定を実施する必要がなく，逆に 表面波を励起する振動源の影響が優勢に認められる日中 の測定が有利である。このように微動の表面波成分に着 目した解析は非常に有効な手法としてほぼ確立されたも のとなっている。

中村 ${ }^{16)}$ は表層地盤の一次固有周期近傍で微動はS 波の 重複反射で説明できる実体波の増幅が見られ，地表面で の水平動と上下動のフーリエスペクトル振幅比をとるこ とにより，表面波の影響を取り除いて安定的に表層地盤 の增幅率が近似的に求まるとしている。地表面での水平 動と上下動のフーリエスペクトル振幅比は, 特に表層地 盤の一次固有周期の近傍で非常に安定した値を示すこと が多くの測定事例 ${ }^{17) ~ 199}$ から示されており，中村 ${ }^{16)}$ の手
$*$ 五洋建設技術研究所第二研究開発室
$* *$ 五洋建設技術研究所第二研究開発室
$* * *$ 五洋建設技術研究所第二研究開発室
$* * *$ 五洋建設技術研究所第二研究開発室

R\&D Div., Research Institute of Technology, Penta-Ocean Construction Co. Ltd.

R\&D Div., Research Institute of Technology, Penta-Ocean Construction Co. Lid.

R\&D Div., Research Institute of Technology, Penta-Ocean Construction Co. Ltd.

R\&D Div., Research Institute of Technology, Penta-Ocean Construction Co. Ltd. 
法の適用性が示されていると考えられる。しかしながら， 表層地盤の一次固有周期の近傍における表面波の影響を 上述の手法で除去しえるとする考え方の確証がないため に，常時微動の主体を表面波であると考えると議論が残 る。例えば，時松ら ${ }^{13)}$ は地表面アレー測定による上下方 向の微動の測定結果から表面波の位相速度にはレイリー 波の分散特性が見られることを示し，さらに地表面での 水平動と上下動のフーリエスペクトル振幅比がレイリー 波の水平動と上下動の振幅比の周期特性に良く対応する ことから，短周期微動にはレイリー波が含まれていると している。しかし，時松ら ${ }^{13)}$ が上下方向の微動からレイ リ一波のものと見られる分散特性を認めた周波数帯は,

微動の水平動と上下動のフーリエスペクトル振幅比が最 大となる表層地盤の一次固有周期近傍よりもより短周期 側のみであり，レイリ一波の水平動と上下動の振幅比の 理論值と観測值の定性的な一致のみの議論となってい る。そのため, 中村 ${ }^{16)}$ の議論の反証とはなり得ない。

一般的に表面波は群速度が極小となる周波数近傍の工 アリ一相で卓越するといわれている ${ }^{20)}$ が，通常の地盤条 件ではレイリー波のエアリ一相はラブ波のエアリー相や 地盤の一次固有周期に比べ高周波数側にある。これまで の短周期の微動を対象とした地表面アレーは，このレイ リー波の卓越する周波数带に着目したものがほとんどで あり，ラブ波のエアリ一相や地盤の一次固有周期近傍に 対応する周波数帯の微動の位相速度の推定のためにはア レ一規模が小さすぎる。また，すでに述べたやや長周期 の微動を対象としたアレ一規模では逆に大きすぎるた め, この周波数帯を対象とした微動のアレ一測定はちょ うど既往の研究のはざまの周波数帯となっている。

そこで，本研究では，ラブ波のエアリ一相や地盤の一 次固有周期に対忘する周波数帯の微動を対象とした比較 的大規模な地表面アレーによる微動測定を行い，同周波 数帯の微動の周波数-波数スペクトルの推定結果から微 動の波群特性を検討した。対象とする波群は主として水 平動が卓越するために，微動のアレー测定により水平動 を主とした测定を実施した。検討対象地点は東京湾周辺 埋立地の 2 地点 ${ }^{191.211}$ であり，すでに小規模の地表面ア レー测定（最大アレー長 $20 \mathrm{~m}$ ）によりレイリー波の分 散特性を有する波群の存在を確認している。ただし，両 地点でのレイリ一波の卓越する周波数帯は表層地盤の一 次固有周期に比べより短周期側となっている。

\section{2. 微動のアレー測定の概要}

微動測定は東京湾周辺の臨海部埋立地である市川市千 鳥町 (以下, 市川と呼ぶ) と袖ヶ浦市奈良輪 (以下, 袖ヶ 浦と呼ぶ）の 2 地点で行った。両地点ともに敷地面積が 広く，目的とする比較的大規模の地表面アレーによる测 定が可能な地点である。市川では敷地の北西に隣接して
JR 京葉線と首都高速湾岸線が並行して通っており, 首 都高速湾岸線は昼夜を問わず交通量が非常に多い。また， 周辺は工場・會庫が建ち並んだ工業地帯の一角に位置し ている。一方, 袖ヶ浦も埋立地の工業用地の一角に位置 しており，約 $2 \mathrm{~km}$ 隔てた北西方向に東電袖ヶ浦発電所 と東京瓦斯袖ヶ浦工場があるが，隣接する地域は資材置 場等の利用が主であり, 明瞭な振動源となる工場等は見 られない。また，周辺交通量は極めて少ない。

この両地点では，ボーリング調査および PS 検層を行 い地盤構造を調べているが，両地点では 1991 年 4 月よ り地中と地表での地震観測を奏施しており，小地震の観 測記録から地盤構造の見直しを行っている。そこでの検 討では，地震観測結果から得られている地中と地表の周 波数伝達関数の観測值と理論上の周波数伝達関数の值が ほぼ対応するように，地盤調查結果から推定された初期 の地盤構造を修正している。このようにして求まった両 地点の地盤速度構造を図一 1,2 に示す。

測定に用いた微動計は，総合周波数特性が約 5 秒以下 で平坦な応答特性をもっている。デー夕は 12 bit の AD 変換器を通して $100 \mathrm{~Hz}$ のサンプリングでパソコンに直 接ディジタル収録した。微動測定は地表面の 8 点に水平

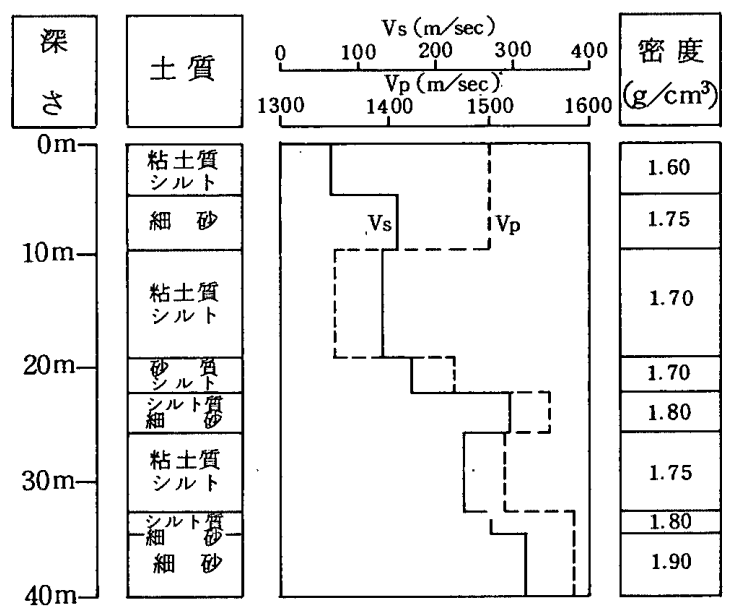

図一1地盤構造（市川）

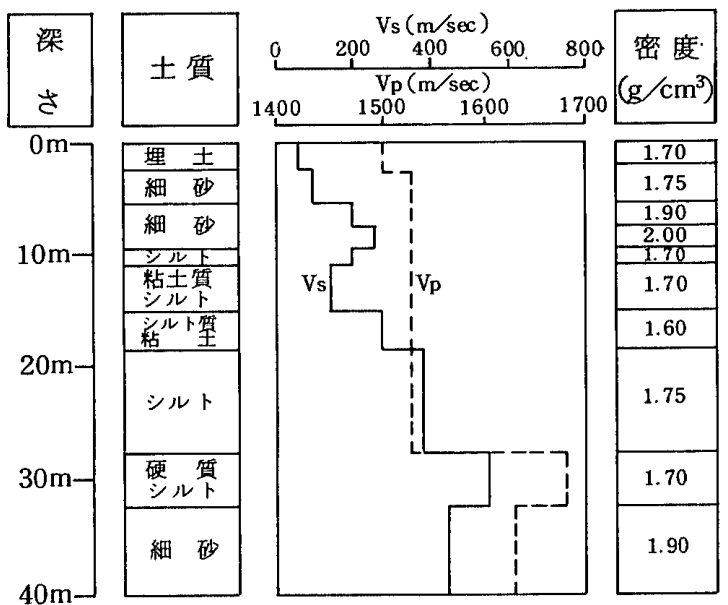

図一2 地盤構造（袖ヶ浦） 

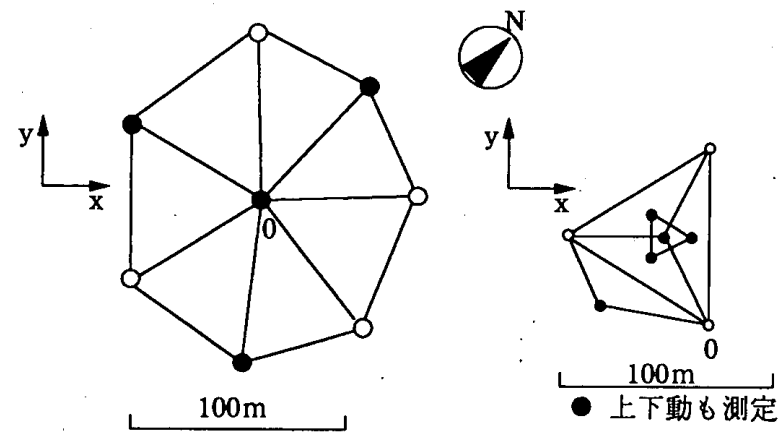

図一3 微動計のアレ一配置（市川）

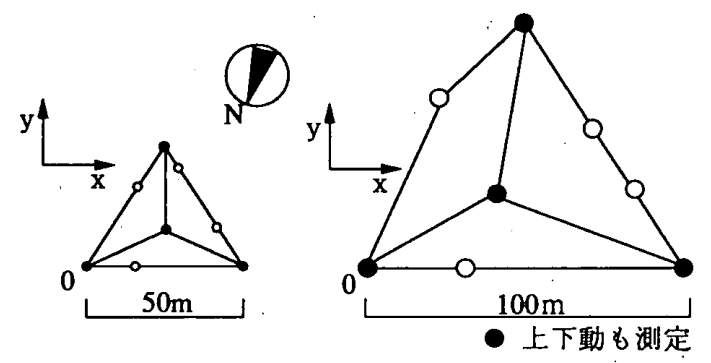

図一4微動計のアレ一配置（袖ヶ浦）

動の微動計を配置して夹施したが，両地点での対象とす る周波数帯の予想される位相速度を考慮して，市川では 図一 3 に示す 2 通りの規模の異なるアレ一配置で, 袖ヶ 浦では図一4に示す 2 通りの規模の異なるアレー配置で の測定を実施した。水平動を測定した 8 点のうちの 4 点 では同時に上下動も测定した。両地点で微動計が若干不 規則な配置となっているのは，敷地の利用条件等により 微動計の設置が制限されたためである。それぞれのア レー配置に対して直交する水平 2 成分（NS および $\mathrm{EW}$ 成分）の測定を数回奏施した。測定は敷地内の作業が終 了した午後 5 時より翌朝 9 時までの約 1 時間おきに，水 平 2 成分にわけた測定をほぼ連続して実施した。

\section{3. 微動の水平動と上下動のフーリエスペクトル}

図一5〜7は市川における微動のフーリエスペクトル を，水平動（NS および $\mathrm{EW}$ 成分）と上下動について示 したものであり，図一8〜10は袖ヶ浦における微動の フーリエスペクトルを水平動と上下動について示したも のである。フーリエスペクトルの計算にあたっては，約 40 秒間（データ個数 4096 個）の記録を解析区間とし, スペクトルの平滑化にはハニングウィンドウを 10 回掛 けている。雨地点ともに 1 地点での記録のうちの 8 回の 测定分を重ねて示している。

市川の水平動のフーリエスペクトルには，測定時間の 違いによるズペクトル振幅の変動が見られるものの，1 秒より短周期側に約 $1.3 \mathrm{~Hz}$ ，約 $2 \mathrm{~Hz}$ および約 $3 \mathrm{~Hz}$ の 3 つの卓越する周波数成分が見られる。ただし約 $2 \mathrm{~Hz}$ の卓越振動成分のスペクトル振幅には水平 2 成分の間で 差が見られ, NS 成分は $\mathrm{EW}$ 成分に比べそのピークは㩆

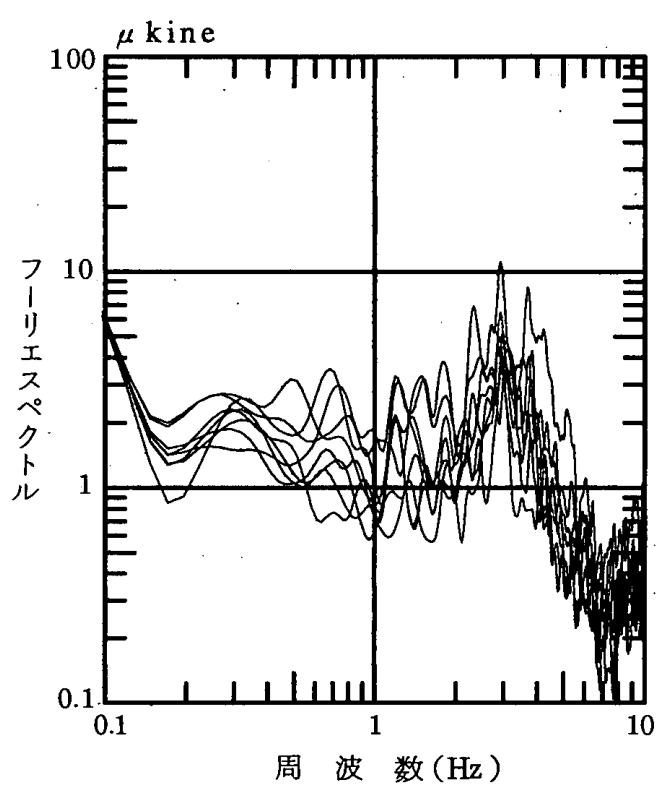

図一5 水平動 (NS) のフーリエスペクトル（市川）

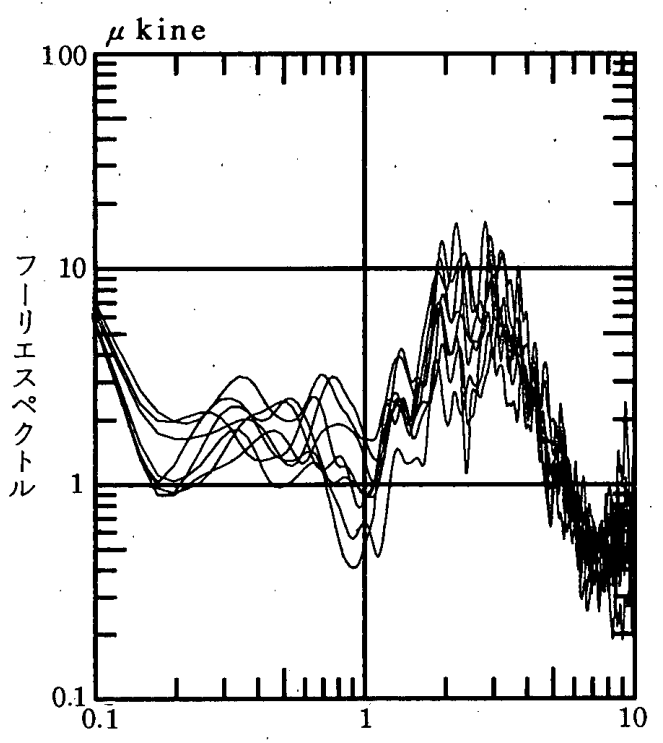

周 波 数 $(\mathrm{Hz})$

図一6 水平動 $(\mathrm{EW})$ のフーリエスペクトル（市川）

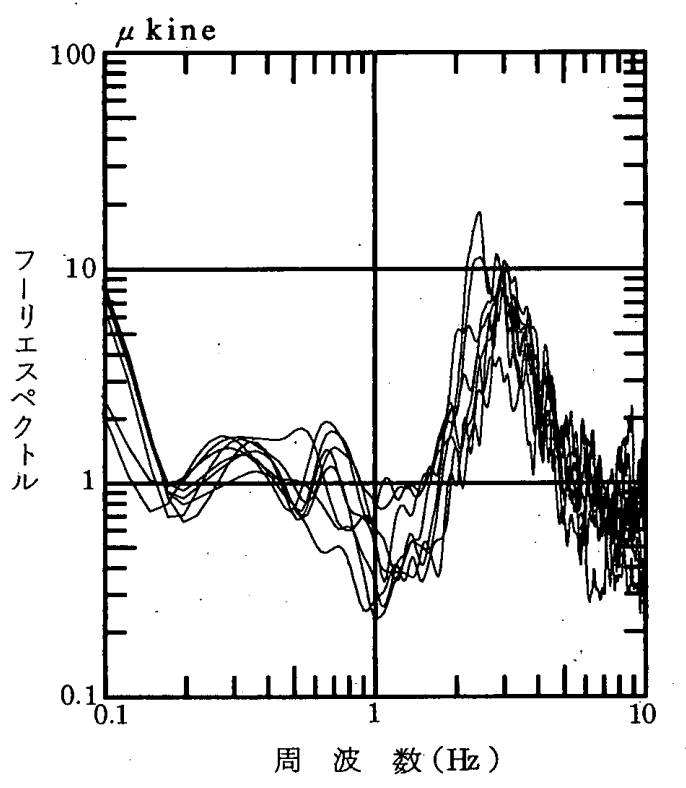

図一7、上動のフーリエスペクトル (市川) 


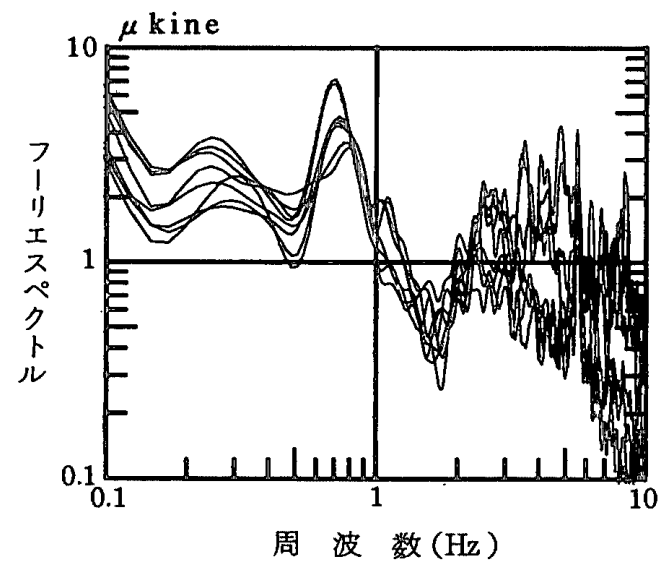

図一8 水平動（NS）のフーリエスペクトル(袖ヶ浦)

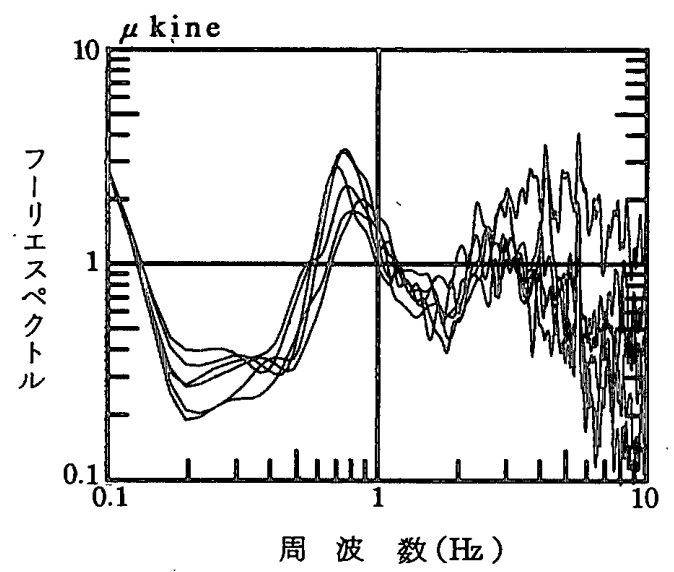

図一9 水平動 $(\mathrm{EW})$ のフーリエスペクトル (袖ヶ浦)

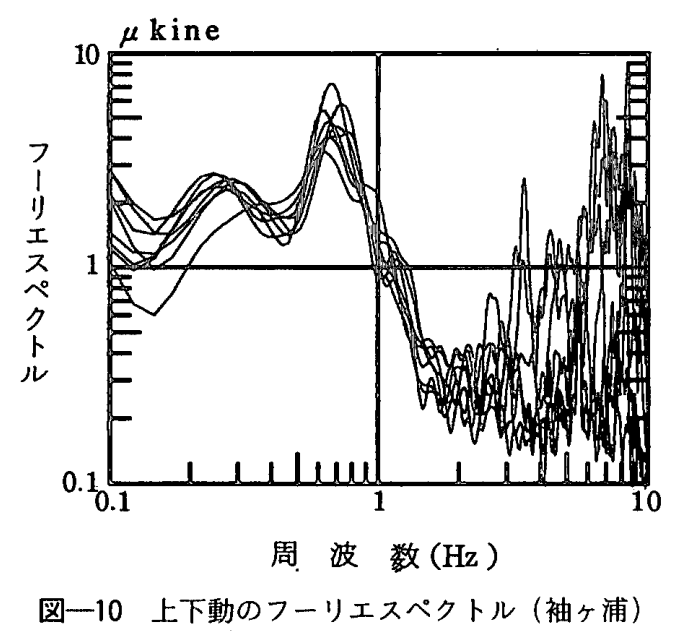

著ではない。一方，上下動には水平動に対応した約 3 $\mathrm{Hz}$ の顕著な卓越周波数成分が見られるのみで，それよ り低周波数側の $1.3 \mathrm{~Hz}$ と約 $2 \mathrm{~Hz}$ の卓越周波数成分は見 られない。

袖ヶ浦の水平動のフーリエスペクトルにも測定時間の 違いによるスペクトル振幅の変動が見られるものの, 1 秒より短周期側の 2 4 Hz に水平動の卓越成分が認めら れる。ただしその卓越振動成分のスペクトル振幅には水 平 2 成分の間に差が見られ，EW 成分はNS 成分に比べ 振幅レベルが比較的低くなっている。一方，上下動には

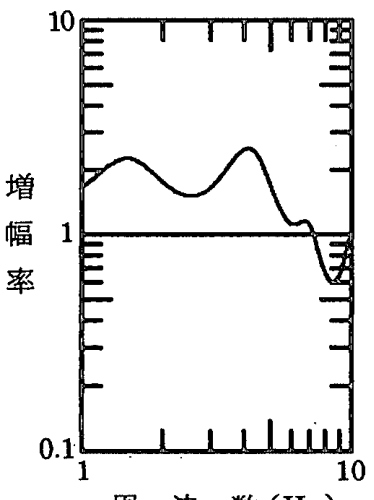

周 波 数 $(\mathrm{Hz})$

図一11表層地盤の増幅率 (市川)

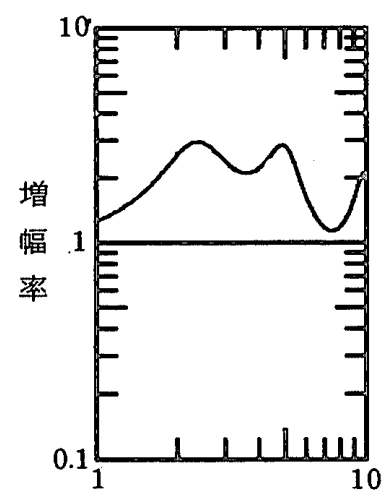

周 波 数 $(\mathrm{Hz})$

図一13 表層地盤の増幅率 (袖ヶ浦)

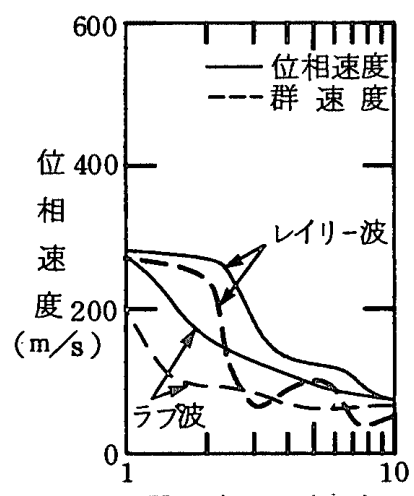

周 波 数 $(\mathrm{Hz})$

図一12 表面波の理諭分散曲線 (市川)

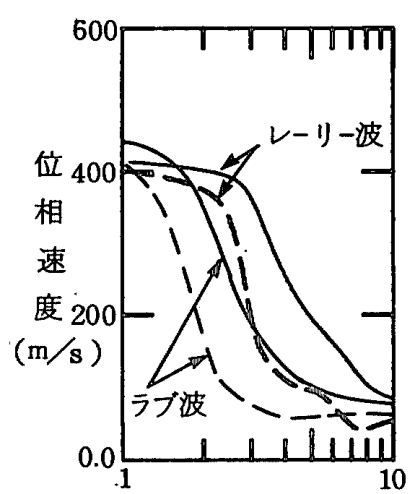

周 波 数 $(\mathrm{Hz})$

図一14 表面波の理論分散曲線 (袖ヶ浦)
これらの周波数帯に対応する明瞭な卓越周波数は見られ ない。

このようなフーリエスペクトルの卓越周波数成分は, 図一 1,2 に示した両地点の表層地盤条件から推定される 実体波と表面波の卓越周波数成分とよく対応している。 図一11, 12 は市川の表層地盤の実体波の増幅率とラブ波 の理論分散曲線およびレイリー波の理論分散曲線を示し たものである。また，図一13，14 は同じく袖ヶ浦の結果 を示したものである。これらの結果から，市川での1〜 $2 \mathrm{~Hz}$ の水平動に見られる卓越振動成分は表層地盤の実 体波の一次固有周期とラブ波のエアリー相に，約 $3 \mathrm{~Hz}$ の波動はレイリー波のエアリー相に対応した波動成分と 考えられる。また, 袖ヶ浦における $2 \sim 4 \mathrm{~Hz}$ の水平動の 卓越振動成分は表層地盤の実体波の一次固有周期とラブ 波のエアリ一相に対応していると考えられる。袖ヶ浦の レイリー波のエアリー相は $5 \mathrm{~Hz}$ より高周波数側に見ら れ，今回の測定では周波数-波数スペクトル解析が可能 となる小規模のアレー配置による測定は実施していな い。なお, 両地点では別途実施した小規模の微動のアレー 測定結果からレイリー波のエアリー相に対応した波動成 分の存在を確認している21)。 
4. 水平動と上下動のフーリエスペクトル振幅比

図一 15,16 は市川之袖ヶ浦の測定結果について, 水平 動と上下動のフーリエスペクトル振幅比を 1 地点の記録 について重ねて示したものである。市川では 1 2 $\mathrm{Hz}$ 付 近で, 袖ヶ浦においては $2 \sim 4 \mathrm{~Hz}$ 付近で水平動と上下動 のフーリエスペクトル振幅比は最大を示し，フーリエス ペクトル振幅に比へ比較的安定した周期特性を示してい る。このような傾向は，両地点で別途実施した微動測定 でも同様の結果が得られており ${ }^{19)}$ ，ほぼ女定的に両地点 に現れる特徵と考えられる。序論でも述べたように中 村 $^{16)}$ と時松ら ${ }^{13)} も こ の$ 定性的な結果については同じ結果 を得ていながらその解釈が異なる。

そこで, 微動の水平動と上下動のフーリエスペクトル

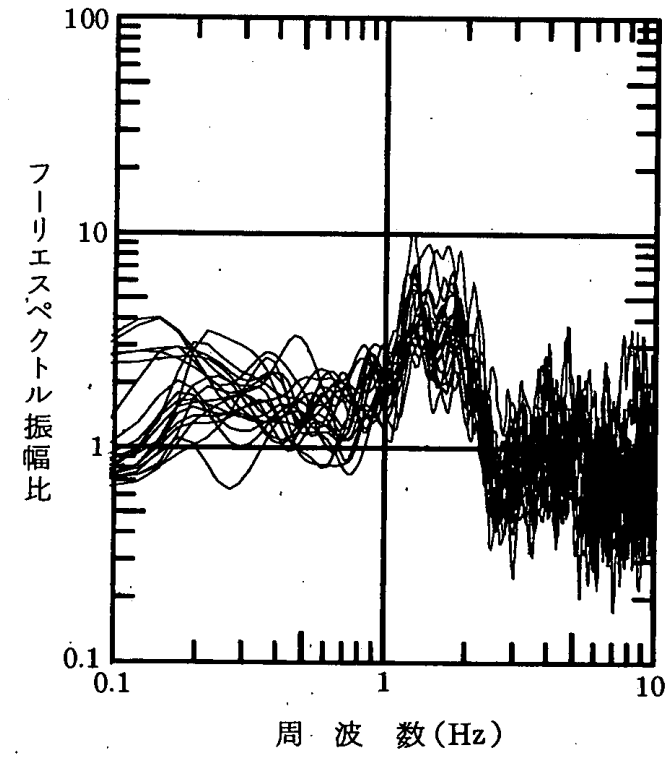

図一15微動の水平動と上下動のフーリエスペクトル振幅比(市 川)

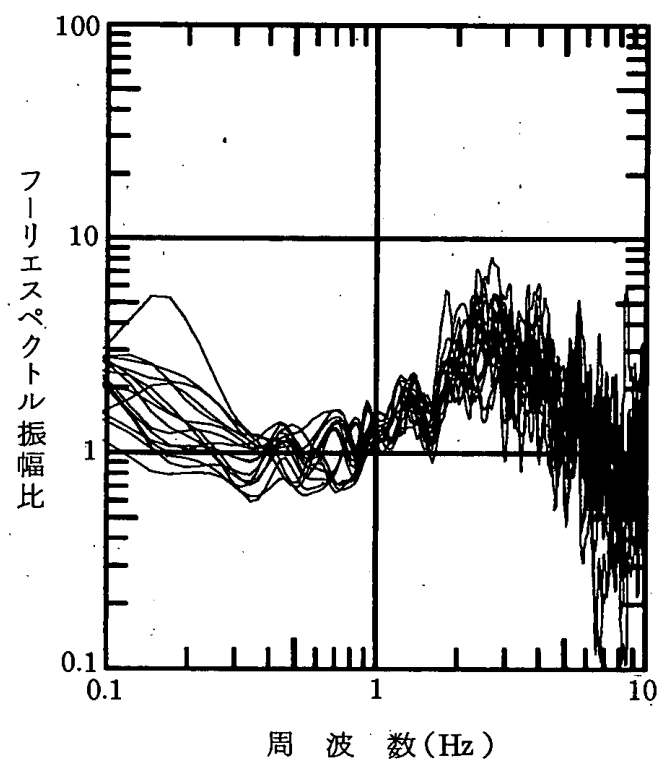

図一16 微動の水平動と上下動のフーリエスペクトル振幅比 (袖ヶ浦)
振幅比を，図一1，2 に示した表層地盤から計算される夷 体波の増幅特性と，レイリー波の基本モードの水平動と 上下動の振幅比をハスケルの理論 ${ }^{22)}$ に基づいて求めたも のの 2 つと比較した。比較にあたって微動の測定結果か ら得られるフーリエスペクトル振幅比は, 複数回実施し た各回のフーリエスペクトル比を各周波数ごとに単純平 均し，得られた值を平均フーリエスペクトル比として表 示した。その結果は図一17，18 に示しているがレイリー 波の基本モードの水平動と上下動の振幅比が発散するこ とを無視すれば，表層地盤の実体波の一次固有周期近傍 においては，レイリー波の基本モードの水平動と上下動

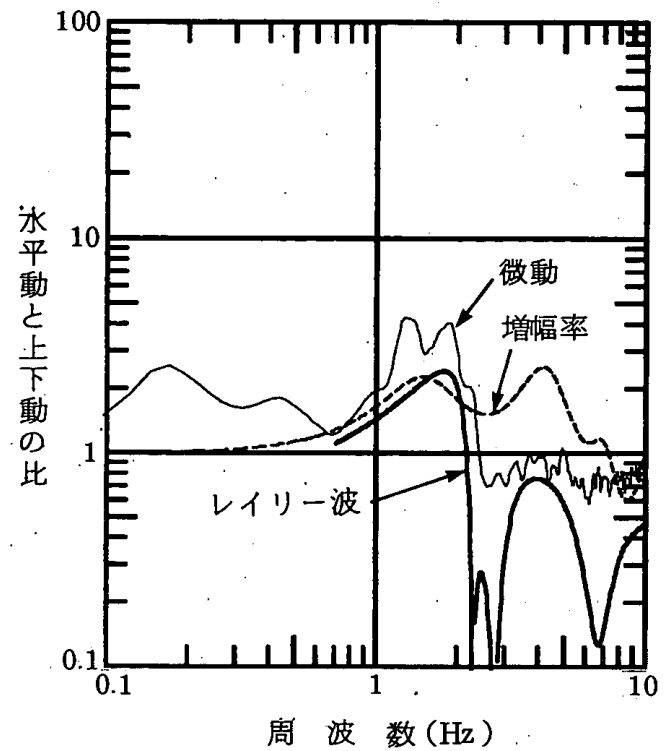

図一17 表層地盤の増幅率とレイリ一波の水平動と上下動の振 幅比と微動の水平動と上下動のフーリエスペクトル振 幅比の比較（市川）

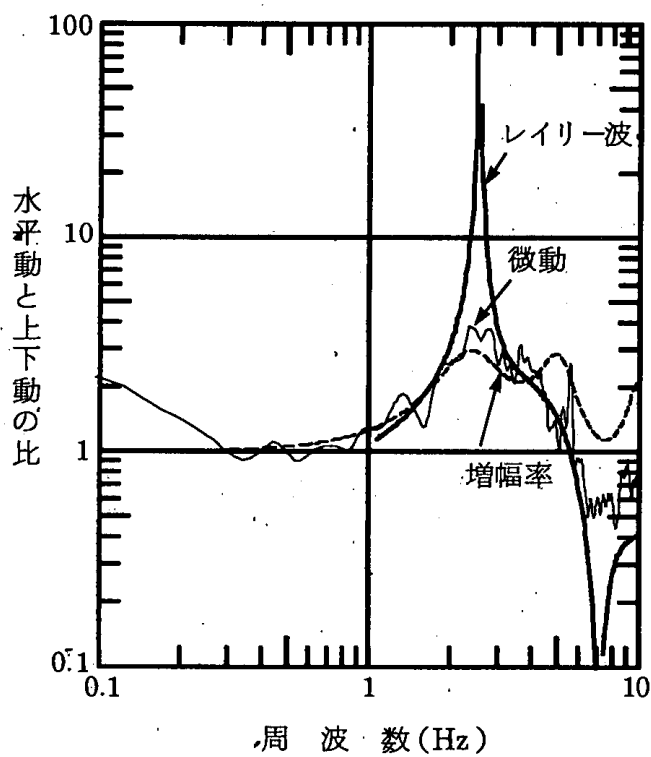

図一18 表層地盤の増幅率とレイリー波の水平動と上下動の振 幅比之微動の水平動と上下動のフーリエスペクトル振 幅比の比較（袖ヶ浦） 
の振幅比と表層地盤の実体波の増幅率はほぼ同様の周期 特性を示すことがわかる。このような傾向は他地点でも 見られるものであり，これらの結果を見る限りは中村 ${ }^{16)}$ と時松ら ${ }^{13)}$ の主張は共に定性的には否定すべきものでは ない上うに思われる。時松ら ${ }^{13)}$ は短周期微動の水平動お よび上下動のそれぞれの振幅が日変化しても, その比が 一定となるのはレイリー波が卓越しているためであると 結諭づけているが，これは中村 ${ }^{16)}$ の仮定条件に立った場 合もその比が一定となることは言えることであり，この ことだけで微動にはレイリ一波が卓越しているとするの は，根拠が不十分と言わざるを得ない。

\section{5. 周波数-波数スペクトルの推定}

ここでは，これまでの議論をふまえて，市川と袖ヶ浦 で測定された微動の水平動のアレー測定結果に対して周 波数一波数スペクトル解析を行い，微動の水平動に見ら れる波群の位相速度とその伝播方向を調べた。周波数一 波数スペクトルの推定方法としては種々のものが提案さ れているが，ここでは分解能の優れたスペクトルが推定 できることから多用されているCaponによる最尤法 $(\mathrm{MLM})^{23)}$ を用いた。周波数-波数スペクトルの推定值 が得られると，2 次元波数空間上でスペクトルのピーク に対応した波数ベクトルから，その波群の持つ位相速度 とその伝播方向が推定できる。

市川での周波数-波数スペクトルの推定は 1 - $2 \mathrm{~Hz}$ を 中心とする周波数帯に対して実施した。すでにフーリエ スペクトルの測定結果で示したように，同周波数帯では NS 成分に比べ $\mathrm{EW}$ 成分が卓越する傾向にあるため，周 波数一波数スペクトル解析は $\mathrm{EW}$ 成分に対して行った。 図一19には 4 つの周波数に対する推定結果の例を示し
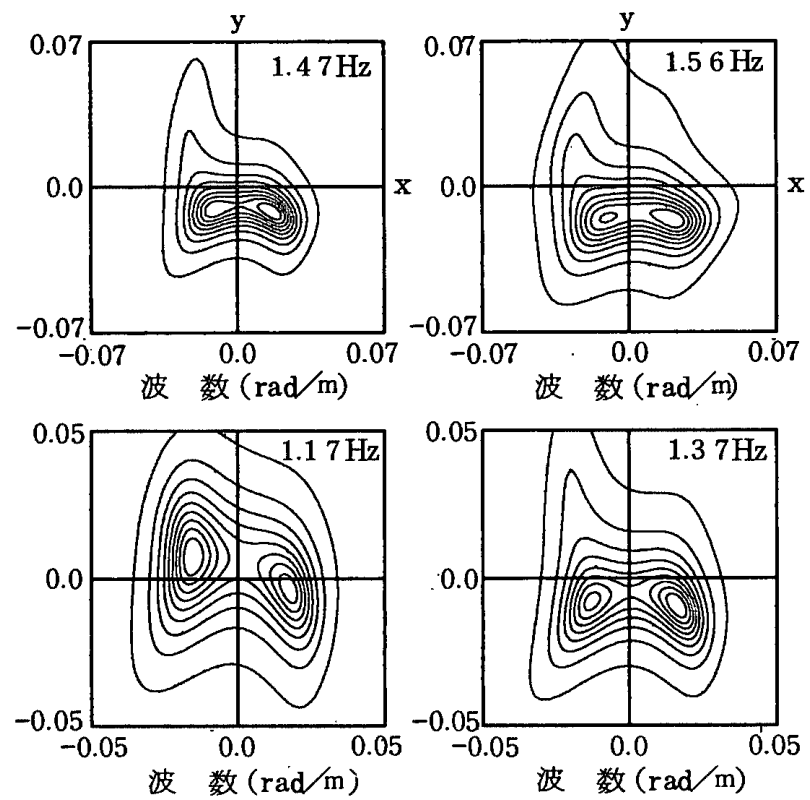

図一19 周波数-波数スペクトルの推定結果（市川）
ている。図一 20 は $2 \sim 4 \mathrm{~Hz}$ を中心とする周波数帯を対 象として求めた袖ヶ浦の結果を示したものである。袖ヶ 浦の場合も市川と同じくフーリエスペクトルの比較か ら，対象と考えた周波数帯において卓越する成分である NS 成分を用い，周波数-波数スペクトル解析を行って いる。周波数-波数スペクトルの推定結果は，それぞれ の周波数に対するスペクトル密度の最大值で正規化した コンターで表示している。

市川の周波数-波数スペクトルの推定結果によれば， これらの周波数帯では複数のスペクトルピークが見ら れ，複数の波群が伝播していることが認められる。袖ヶ 浦の周波数-波数スペクトルの推定結果にも同様の傾向 が認められ，対象とした周波数帯においては複数の波群 が伝播していると考えられる。それぞれの波群の持つ位 相速度およびその伝播方向については，周波数-波数ス ペクトルが最大值を示す波数べクトルに対する值で代表 させるものとしたが, 複数の波群の伝播が確認されたも のについては，それぞれのスペクトルピークに対する位 相速度とその伝播方向も計算した。図一-21, 22 は市川と 袖ヶ浦のそれぞれの地点について，ラブ波の理論分散曲 線と周波数一波数スペクトルの推定值から求まる各波群 の位相速度とを比較したものである。図中の○印が 2 番 目以降のスペクトルピークの值を示したものである。

図一21によれば，市川ではラブ波の理論分散曲線に 対応した位相速度を持つ波群と $300 \sim 500 \mathrm{~m} / \mathrm{s}$ の比較的 速い位相速度をもつ波群の 2 つに大きく分けることがで きる，両波群は約 $1.3 \mathrm{~Hz}$ 付近を境亡して，それより長 周期側では 300 $500 \mathrm{~m} / \mathrm{s}$ の位相速度を持つ波群が， 1.3 $\mathrm{Hz}$ より短周期側ではラブ波に対応した位相速度を持つ 波群が卓越していることがわかる。これらの結果から，
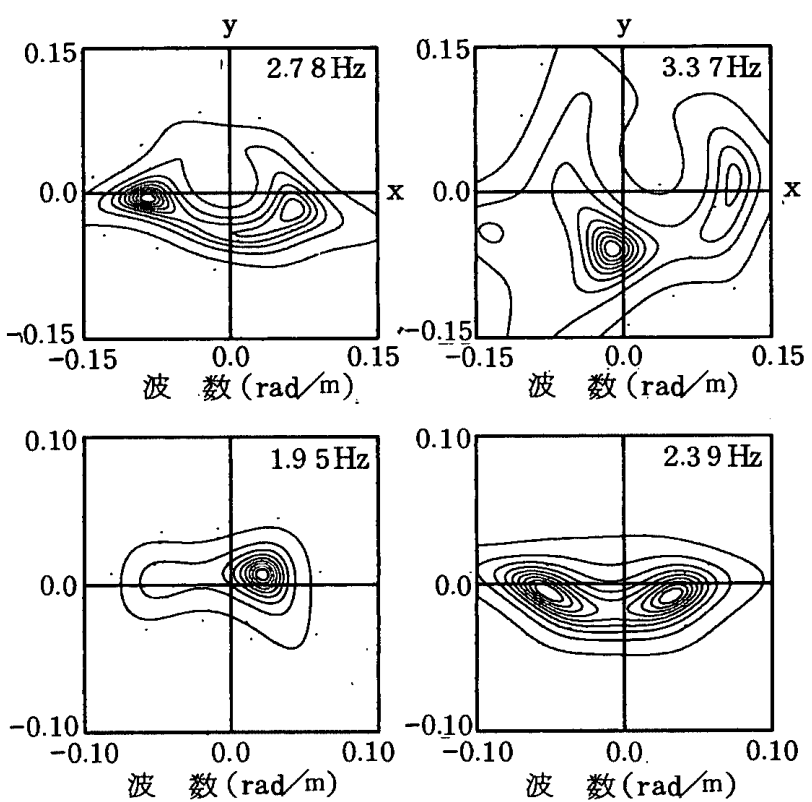

図一20 周波数-波数スペクトルの推定結果（袖ヶ浦） 


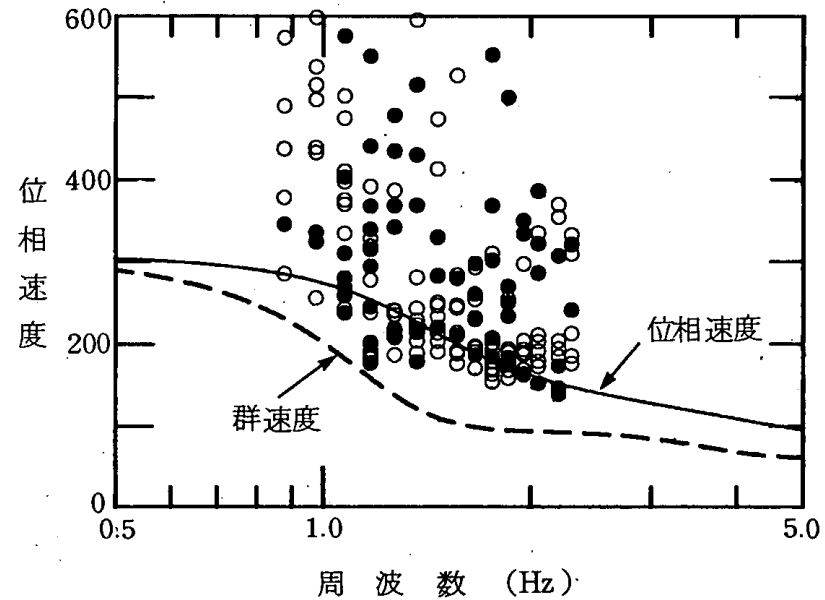

、図一21 周波数-波数スペクトル上り求めた位相速度とラブ波の 理論分散曲線との比較（市川）

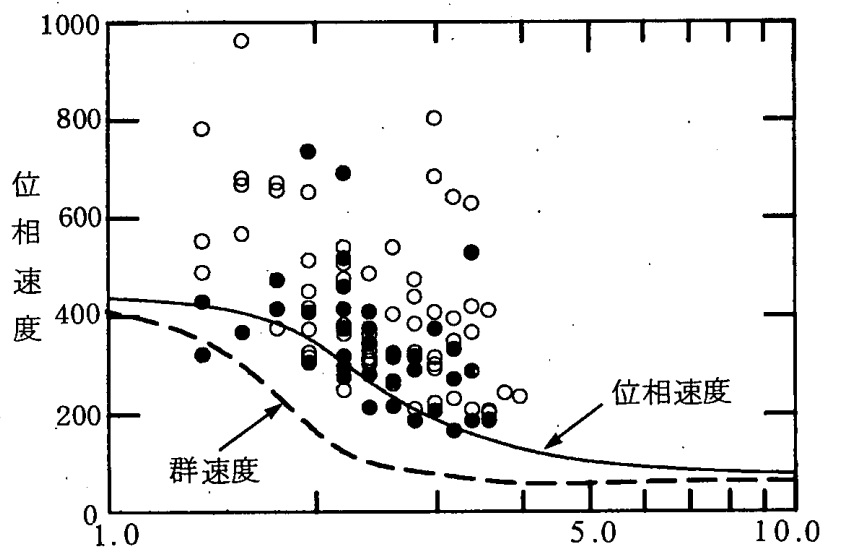

周 波 数 $(\mathrm{Hz})$

図一 22 周波数-波数スペクトル上り求めた位相速度とラプ波の 理論分散曲線との比較（袖ヶ浦）

1 2 $\mathrm{Hz}$ の周波数帯ではラブ波の分散特性を有する波群 が認められ，特に $1.3 \mathrm{~Hz}$ より高周波数側で卓越してい ると考えられる。また, 地表面での位相速度が 300 $500 \mathrm{~m} / \mathrm{s}$ を有する波群も同周波数帯に認められるが, 地 盤調査で確認されている最深部の地層のせん断波速度で ある $300 \mathrm{~m} / \mathrm{s}$ を超える值を示している。これらの波群は, せん断波速度がほぼ同程度の値を有するやや深い深度に 存在する地層を伝播している波群が表層地盤へ実体波と して伝播している波動か，より深い地下構造を反映しだ 表面波として伝播している波動かのいずれかと考えるこ とができる。しかし，市川においては図一1に示した表 層地盤より深い地下構造は現在のところ得られていない ため，この結果だけからではそのいずれであるかを結論 づけることはできない。

一方，図一 22 の袖ヶ浦の結果にも市川と同様の傾向 が認められ，2〜4 Hz の周波数帯において，ラブ波の理 論分散曲線に対応した波群と，それより速い 400 - 800 $\mathrm{m} / \mathrm{s}$ の位相速度を持つ波群とに大きく分けることができ る。ただし，ラブ波の理論分散曲線との対応は市川ほよ゙

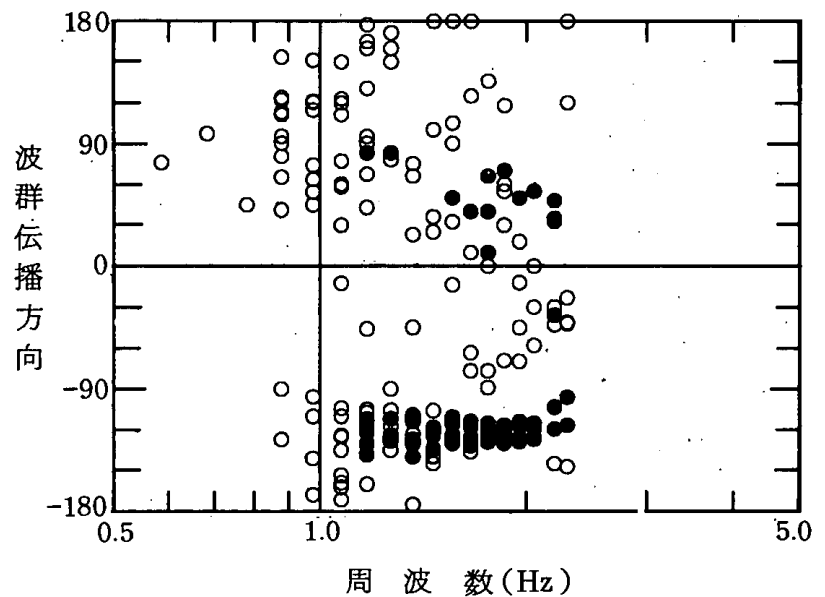

図一23 波群伝播方向の推定結果（市川） $x$ 軸正方向より反時計回りを正としている

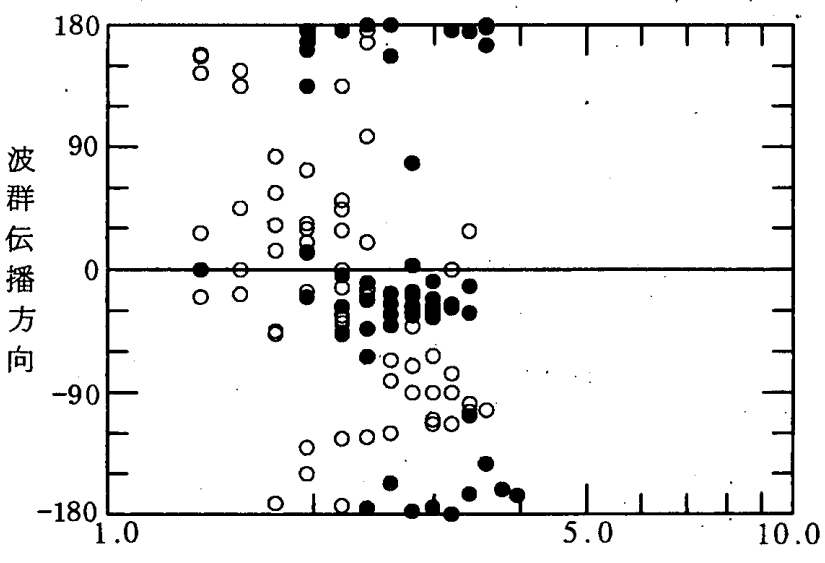

周”波 数 $(\mathrm{Hz})$

図一24 波群伝播方向の推定結果（袖ヶ浦）

明確ではない。これらの結果は $2 \sim 4 \mathrm{~Hz}$ の周波数帯では， 袖ヶ浦においても市川と同様の地盤震動環境にあること を示唆するものと考えられる。

このように市川と袖ヶ浦においては，ラブ波の分散特 性を有する波群に加えて, 市川では 300 500 m/s の值 を, 袖ヶ浦では 400 ～ $800 \mathrm{~m} / \mathrm{s}$ の值を示す比較的速い速 度で伝播する波群が観測されている。

図一23，24.は両地点での各波群の伝播方向を示したも のである。図中のの印は，両地点においてラブ波の分散 性を持つ之考えられる波群の伝播方向を，○印はラブ波 の位相速度より速い位相速度を有する波群の伝播方向を 示したものである。これによれば，市川ではラブ波と考 えられる波群の伝播方向は各測定時間ともにほぼー 120 度の方向（ほぼNからS方向に対応し; 陸地側から海側 に伝播していることになる）に集中しているのに対し， より速い位相速度を有する波群の伝播方向は各測定時間 によるばらつきが大きい。市川ではラブ波と考えられる 波群の伝播方向はNS 方向に認められる結果となった が，NS 方向に伝播するラブ波の地盤震動は進行方向に 
直交するEW 方向が卓越すると考えられる。今回の測 定では水平 2 方向の同時計測を実施していないため, パーティクルオービットによる地盤振動方向の確認はで きないが, 図一 5,6 に示した水平 2 成分のフーリエスペ クトルの約 $2 \mathrm{~Hz}$ 近傍のスペクトル振幅は $\mathrm{EW}$ 成分が卓 越しており，この波群をラブ波と考えることを支持する ものと考える。一方, 袖ヶ浦でもほぼ同様の結果を示し ており, ラブ波の分散特性を有する波群はほぼ安定して -30 度の方向と 180 度の方向（ほぼE方向と NW 方向） に見られるのに対し，ラブ波の位相速度より速い位相速 度を有する波群の伝播方向のばらつきは大きい。袖ヶ浦 においても水平 2 成分の同時測定を実施していないが, ここで示したラプ波の分散特性を有する波群の伝播方向 は, 図一8, 9 に示したフーリエスペクトルの約 2 $-4 \mathrm{~Hz}$ 近傍のスペクトル振幅の水平 2 成分の差異と調和した結 果となっている。これらの結果は, ラブ波の分散性を有 する波群がラブ波として伝播していることを支持する結 果の一つと考えられる。

今回の水平動を用いた測定結果からは, 表層地盤の実 体波の一次固有周期近傍において, 微動にはレイリー波 の分散特性を有する波群の存在は明確には認められず, ラブ波の分散特性を有する波群についてのみその存在が. 確認できた。前出の地表面における微動の水平動亡上下 動の振幅比に関する議論のうち, 時松ら ${ }^{131}$ が示したよう なレイリー波の卓越による水平動と上下動の振幅比に関 する説明は, 今回解析対象とした周波数帯においてはな りたたない。一方，中村 ${ }^{16)}$ が示している基盤層を伝播す る波動が表層へ実体波として伝播しているとする考え方 について, その可能性を否定することは今回の測定結果 ではできない。ただし，中村 ${ }^{16)}$ 考え方には基盤層にお ける水平動と上下動の振幅レベル, すなわちスペクトル 振幅がほぼ同じとする大きな仮定条件が必要であること や，水平動には今回の測定結果からも明らかになったよ うな表面波として伝播する波動も含まれているなどの, 手法の妥当性を検証するために残されている課題も少な くない。そのため, 同手法は工学的近似手法, すなわち 表層地盤の卓越周期を簡便かつかなりの精度で推定する 手法として受け入れられるべきであろう。

\section{6. 結 論}

地盤構造があらかじめわかっている市川と袖ヶ浦にお いて, 表層地盤のS 波重複反射に基づく一次固有周波数 近傍の周波数帯の微動を対象とした, 微動の地表面ア レー測定を実施し，同周波数近傍に認められる波群の特 性に関して以下のような結論を得た。

1）地表面における水平動と上下動のフーリエスペクト ル振幅比は安定した周波数特性を示し, それらは表層地 盤での S 波重複反射に基づく水平動の増幅率とレイリー
波の水平動と上下動の振幅比とに良く対応している。

2）両地点の表面波の理論分散曲線から求まるエアリー 相は, ラブ波の場合には表層地盤の S 波重複反射に基づ く一次固有周期とほぼ近い值を示すが, レイリ一波の場 合にはそれより高周波数側に表れる。

3）市川では表層地盤のS 波重複反射に基づく一次固有 周波数近傍の周波数帯において, ラブ波の分散特性を有 する波群と基盤のせん断波速度を超える位相速度を持つ 波群の $2 つ$ 波群が見られ, $1.3 \mathrm{~Hz}$ を境として短周期 側ではラブ波の分散性を有する波動が, 長周期側では基 盤のせん断波速度を超える速度で伝播する波動が卓越す る傾向にある。

4）袖ヶ浦においても表層地盤のS 波重複反射に基づく 一次固有周波数近傍では, ラブ波の分散特性を有する波 群と基盤のせん断波速度を超える位相速度を有する波群 が見られる。

5）周辺の振動源の特性によっては表面波の特性を有す る波群も存在するが, 表層地盤の一次固有周期近傍にお いてはレイリー波よりラブ波が卓越する傾向にある。

今回の測定結果により，適切なアレー長を設定すれば 表層地盤の S 波重複反射に基づく一次固有周期近傍の周 波数帯の微動の波群識別にも, 微動の地表面アレー測定 は有力であることがわかった。また,これらの結果から 同周波数帯の微動の種別に関する若干の考察を加えた。 ただし，一般的な微動の特性を議論するためには，対象 とする個々の地点の詳練な現地測定に基づく解析結果を 得ることが必要である。微動は地盤特性と振動源の特性 を極めて忠実に再現するものであり，これらの特性を適 切に評価することにより, 微動を利用した地盤特性の検 討の有効性が今後さらに高まるものと考えられる。

\section{謝 辞}

本研究の遂行にあたり宇都宮大学工学部入江助教授に は貴重なご討議を頂きました。記して謝意を表する次第 です。

\section{参考文献}

1) 金井 清：地震工学, 共立出版, 1972

2）堀家正則：微動の位相速度および伝達関数の推定, 地震 第 2, 第 33 巻, pp. $425-442,1980$

3）岡田 広, 松島 健：長周期微動の観測による厚い地盤 構造の推定について, 第 7 回日本地震工学シンボジウム, pp. $211 \sim 215,1986$

4）岡田 広, 松島 健, 日高英治 : 長周期微動に含まれる 表面波の位相速度推定法について一空間自己相関法と周 波数一波数法の比較一, 北海道大学地球物理学研究報告 No. 49, pp. 53 62, March 1987

5）松島 健, 小柳敏郎, 岡田 広, 森谷武男, 笹谷 努, 坂尻直巳, 宮腰 研 : 長周期微動を用いた十勝平野の深 層地盤構造の推定 (2), 地霞学会講演予稿集 1991 年度 秋季大会, p. 281, 1991, No.2 
6) T. Sato, H. Kawase, M. Matsui and S. Kataoka : Array Measurement of High Frequency Microtremors for Underground Structure Estimation, Fourth International Conference on Seismic Zonation, August 26-29, 1991

7) 佐藤俊明, 川瀨 博, 松井正宏, 片岡俊一：アレー観測 された短周期上下微動 (周期約 0.2-0.5 秒) と地下構造 (そ の 1) (その 3), 日本建築学会大会 (東北) 梗概集 B, pp. $449 \sim 454,1991$

8）片岡俊一, 松井正宏, 佐藤俊明, 川瀬 博: 東京都江東 区越中島でアレー観測された微動から地下構造を求める 試み, 地震学会講演予稿集 1991 年度秋季大会, p. 147, 1991, No. 2

9）松井正宏, 片岡俊一, 佐藤俊明：地盤の短周期常時微動 に関する研究 人工震源実験および小アレー観測による 上下成分の検討, 日本建築学会大会 (北陸) 梗概集 B, pp. 473〜474, 1992

10）微動アレイ観測グループ：メキシコ市内における微動ア レイ観測による $\mathrm{S}$ 波速度構造の推定, 地霞学会講演予稿 集 1992 年度春期大会，p. $42 ， 1992 ， N o .1$

11）時松孝次, 新澤健一郎：短周期微動のアレイ観測に基づ <表層 S 波速度構造同定の可能性, 第 27 回土質工学研究 発表会, pp. 963 964, 平成 4 年. 6 月

12）時松孝次, 酒井潤也, 仲條有二：短周期微動の水平鈶直 振幅比と地盤構造の関係, 日本建築学会大会 (北陸) 梗 概集 B，pp. 473〜 474，1992

13）時松孝次, 宮寺泰生：短周期微動に含まれるレイリー波 の特性と地盤構造の関係, 日本建築学会構造系諭文報告 集第 439 号, pp. 81 89, 1992 年 9 月
14）㖕川三郎：チリ中央部の強震観測点の地盤特性, 地震学 会講演予稿集 1992 年度春期大会, p. 48, 1992, No. 1

15）田村 保, 永井大海: 東京湾臨海部埋立地での常時微動 測定（その3), (その4), 日本建築学会大会 (北陸) 梗 概集 B, pp. 419 422，1992

16）中村 豊：常時微動計測に基づぐ表層地盤の地震動特性 の推定，鉄道総研報告，pp. 18 27, 1988

17）大町達夫, 年縄 巧, 茂木秀則：常時微動から推定した 臨海埋立地盤の振動特性, 土木学会第 45 回年次学術講演 会, pp. $1066 \sim 1067$, 平成 2 年 9 月

18）中村 豊, 滝沢太郎：常時微動による東京湾大井埠頭周 辺地盤の地震動特性の推定, 第 8 回日本地震工学シンポ ジウム, pp. 679〜684, 1990

19）田村 保, 永井大海, 入江康隆：東京湾臨海部埋立地で の常時微動測定, 土木学会第 46 回年次学術講演会講演梗 概集 第 1 部, pp. 1272 1 273, 1991

20）䳋 悦三:やさしい地震学入閂, 鹿島出版会, 1990

21）永井大海, 田村 保: 東京湾臨海部埋立地での地震観測 之常時微動測定, 土木学会第 47 回年次学術講演会講演梗 概集 第 1 部, pp. $1272 \sim 1273,1992$

22) Haskell, N. A. : The Dispersion of Surface Waves on Multilayered Media, Bulletin of the Seismological Society of America, Vol.43, No. 1, pp. 17 34, 1953

23) Capon, J. : High-resolution Frequency-Wavenumber Spectrum Analysis, Proc. IEEE 57, pp.1 408 1 418, 1969

(1992 年 11 月 4 日原稿受理, 1993 年 4 月 6 日採用決定) 